УДК 34:378.14

DOI https://doi.org/10.52726/as.pedagogy/2021.3.1.21

\author{
М. А. ХЛИСТІК \\ старший викладач кафедри права, \\ Приватний вищий навчальний заклад "Академія рекреаџійних технологій і права», \\ м. Луцььк, Україна, \\ Електронна пошта: mirahlystik@gmail.com \\ http://orcid.org/0000-0002-7154-2320
}

\title{
ЗМІСТ ПОНЯТТЯ «ІННОВАЦЙНН МЕТОДИ НАВЧАННЯ У СФЕРІ ВИКЛАДАННЯ ПРАВНИЧИХ ДИСЦИПЛІН»
}

\begin{abstract}
У статті розглянуто теоретичні підходи до змісту та визначення категорій «інновація», «освітня інновація», «інноваційний метод навчання», «інноваційні методи навчання у сфері викладання правничих дисциплін». Проаналізовано погляди різноманітних вчених до визначення цих категорій. Досліджено нормативно-правові акти, у яких можна віднайти вказані дефініції. Запропоновано авторське трактування окремих з них.

Виходячи із найбільш розповсюджених тлумачень термінів «метод навчання», «інновація», «освітня інновація», запропоновано сформулювали таке визначення поняття «інноваційний метод навчання» - це сукупність способів і прийомів навчання певної дисципліни, що відповідають вимогам сьогодення, істотно підвищують якість, ефективність та результативність навчально-виховного процесу, сприяють інтенсифікації та модернізації навчального процесу, розвивають творчий підхід і особистісний потенціал його учасників.

Враховуючи зміст Положення про порядок здійснення інноваційної освітньої діяльності, подано таке тлумачення терміну «інноваційний метод навчання» - це об'єкт інноваційної освітньої діяльності, новостворений (застосований) або вдосконалений метод у галузі освіти, що істотно підвищує якість, результативність та ефективність освітньої діяльності педагогічних та науково-педагогічних працівників, навчальних закладів.

Зроблено висновок, що інноваційні методи навчання у сфері викладання правничих дисциплін - це сукупність способів і прийомів навчання правничих дисциплін, що відповідають вимогам сьогодення, істотно підвищують якість, ефективність та результативність навчально-виховного процесу, сприяють інтенсифікації та модернізації навчального процесу, розвивають творчий підхід і особистісний потенціал його учасників, забезпечують набуття в процесі навчання студентами-правниками необхідних компетентностей.
\end{abstract}

Ключові слова: інновації, освітні інновації, інноваційні методи навчання, інноваційні методи навчання у сфері права, юридична освіта.

Постановка проблеми. Період після 2014 року в Україні характеризується значними змінами та реформами в усіх сферах життя. В умовах загального контексту європейського інтегрування істотних трансформацій зазнає і вища освіта України, у тому числі й юридична. Відповідно до Закону України «Про вищу освіту» одним із основних принципів, на яких грунтується державна політика у сфері вищої освіти, є принцип міжнародної інтеграції системи вищої освіти України у Свропейський простір вищої освіти, за умови збереження і розвитку досягнень та прогресивних традицій національної вищої школи [Про вищу освіту].

Сьогодні гостро постала проблема, яка потребує розв'язання, - «невідповідність змісту юридичної освіти і якості підготовки в правничих школах сучасним вимогам ринку праці та викликам, що стоять перед сучасним демократичним суспільством, глобальним тенден- ціям розвитку та завданням професійної діяльності правників у різних сферах» [Концепція].

Не так давно Всеукраїнською громадською організацією «Українська Асоціація Маркетингу» за підтримки Агентства США з міжнародного розвитку (USAID) в рамках Проєкту «Справедливе правосуддя» були проведені дослідження на тему: «Залучення громадськості до формування рамки кваліфікацій правничої професії шляхом проведення аналізу обсягу знань, переліку навичок і вмінь, якими має володіти випускник юридичного вищого навчального закладу, щоб відповідати вимогам сучасного ринку праці». Результати досліджень показали, що загалом зміст і методологія викладання в українських вищих правничих школах зберігають радянські підходи, що впливає на розуміння права студентами-правниками та імідж правничої професії [Аналітичний : 6]. 
Аналіз попередніх досліджень. Проблеми впровадження інноваційних процесів та методів у вищу освіту стали об'єктом вивчення як зарубіжних, так і українських учених. Зокрема, наукові дослідження у цій сфері проводили А. М. Алексюк, I. I. Доброскок, Г. П. Коцур, С. О. Нікітчина, Г. П. Клімова, В. Г. Кремень, В. В. Ільїн, С. В. Пролеєв, М. В. Лисенко, П. Ю. Саух, О. В. Чумак та інші.

Особливості професійної підготовки юристів, правничу науку, юридичну педагогіку висвітлювали такі науковці, як В. І. Андрейцев, В. Г. Чужикова, С. Д. Гусарев, С. С. Сливка, В. Я. Кікоть, А. М Столяренко та інші.

Питання модернізації вищої юридичної освіти та застосування інновацій у сфері підготовки студентів-правників предметно вивчали Н. В. Артикуца, В. М. Куц, О. В. Топчій, О. В. Фатхутдінова, О. В. Василенко та інші.

Проте питання визначення терміну «інноваційні методи навчання та їх практичне застосування в процесі викладання правничих дисциплін» є відкритим і сьогодні, а думки з цього приводу різняться та $є$ неоднозначними.

Мета статті - на основі аналізу різних підходів вчених розкрити сутність та особливості поняття «інноваційні методи навчання у сфері викладання правничих дисциплін».

Виклад основного матеріалу. Високий рівень суспільної відповідальності юристів, зумовлений вимогами до їх професійної діяльності, значна конкуренція на ринку надання освітніх послуг вимагають від закладів вищої освіти активно впроваджувати нові методи та форми навчання студентів-правників.

Інноваційні методи викладання правничих дисциплін заслуговують на особливу увагу, оскільки впровадження інноваційних технологій у навчальний процес допомагає готувати висококваліфікованих, конкурентноспроможних правників.

Поняття «інновація» сьогодні досить часто вживається у вітчизняному лексиконі, хоча актуалізувалось воно у науковій та освітянській сфері лише наприкінці XX століття. Сьогодні не існує єдиного загальноприйнятного визначення поняття «інновація». Більшість асоціюють його 3 нововведеннями, цілеспрямованими змінами.

Поширені різні, часто суперечливі точки зору стосовно того, що слід вважати інноваці- ями - абсолютно нове чи вдосконалене старе, глобальні чи локальні зміни, процес створення нового чи його результат, будь-що нове чи лише те, що є актуальним і значущим, тощо.

У «Словнику іншомовних слів» за редакцією О. С. Мельничука (1974 року) слово «інновація» та похідні від цього терміну слова взагалі відсутні [Словник 1974]. Запозичене 3 англійської мови слово інновація (англ. innovation від лат. innovatio - оновлення, зміна) у «Словнику іншомовних термінів» (2000р.) зареєстроване у значеннях: 1) нововведення в галузі економіки, техніки тощо на основі досягнень науки і передового досвіду; 2) нове явище в мові (мовозн.). Там же наведений і похідний термін «інноваційний» - «який стосується інновацій»; «інноваційний банк» - банк, який здійснює кредитування і фінансування інновацій у науково-технічній і організаційно-управлінській сферах» [Словник 2000 : 230]. У «Юридичній енциклопедії» можемо віднайти визначення лише словосполучення «інноваційне законодавство» - (від лат. innovation - поновлення, зміна) - специфічна комплексна галузь законодавства, якою регулюються суспільні відносини в процесі здійснення організаційних, фінансових, інвестиційних, матеріальнотехнічних та інших заходів, спрямованих на створення і впровадження науково-технічних розробок, нової техніки і технологій, нових форм організації праці та управління, освоєння і випуск нових видів продукції» [Юридична].

Не вдалося віднайти тлумачення терміну «інновація» та похідних від нього слів та словосполучень в Українському педагогічному словнику 1997 року [Український].

«Енциклопедія освіти», яка була видана у 2008 р. Академією педагогічних наук України, теж не містить роз'яснень понять «інновація», «інноваційні методи» тощо [Енциклопедія]. Проте до 2-го видання цієї енциклопедії, яке готується до друку колективом вчених Національної Академії педагогічних наук України, вже заплановано включити такі терміни, як «інноватика», «інновації в освіті», «інноваційні технології в освіті».

Як бачимо, сьогодні у тлумачних словниках не закріплене спеціальне значення терміна інновації, пов'язане 3 освітянською сферою. Водночас у сучасній педагогічній та науково- 
методичній літературі термін цей, як і прикметник інноваційний, $\epsilon$ широко вживаним.

Н. Артикуца сутність інновацій щодо вищої освіти сформулювала у декількох варіантах: «інновації - це нововведення на основі досягнень науки, освіти, передового педагогічного та управлінського досвіду, покликані стимулювати розвиток прогресивних і високоефективних освітніх технологій», та більш розгорнуто: «інновації - це нові перспективні тенденції, процеси та підходи у розвитку сучасної вищої освіти, які грунтуються на поєднанні наукової та освітньої діяльності, теорії з практикою, інтеграції та диференціації сучасних знань, фундаментальної підготовки фахівців із вузькопрофільною спеціалізацією та спрямовані на модернізацію, підвищення якості та ефективності сучасного навчального процесу» [Артикуца : 4].

Термін «освітні інновації» та пов'язані з ним вдалося віднайти у Положенні про порядок здійснення інноваційної освітньої діяльності, затвердженому наказом Міністерства науки і освіти України від 07 листопада 2000 року № 522 (далі - Положення) [Положення]. Редакція цього Положення кілька разів змінювалась, при цьому дещо по-іншому трактувались і значення вищевказаних термінів (див. табл.).

Отже, відповідно до Положення освітня інновація - це новостворені (застосовані) або вдосконалені освітні, навчальні, виховні, психолого-педагогічні та управлінські технології, методи, моделі, продукція, освітні, а також технічні рішення у галузі освіти, що істотно підвищують якість, результативність та ефективність освітньої діяльності. Тобто освітня інновація це не просто новий або вдосконалений освітній продукт, це продукт, результатом застосування якого є покращення діяльності у сфері освіти.

Похідний термін «інноваційний» у науково-педагогічній та методичній літературі найчастіше вживається у складі термінологічних словосполучень: інноваційний метод, інноваційна методика, інноваційний підхід, інноваційні технології тощо.

Таблиця

Значення термінів «інноваційна освітня діяльність», «освітні інновації», «об'єкти інноваційної освітньої діяльності» у різних редакціях Положення про порядок здійснення інноваційної освітньої діяльності

\begin{tabular}{|c|c|}
\hline \multicolumn{2}{|r|}{ Визначення терміну «інноваційна освітня діяльність» } \\
\hline $\begin{array}{c}\text { Редакція від } \\
07.11 .2000 \\
\end{array}$ & розробка, розповсюдження та застосування освітніх інновацій \\
\hline $\begin{array}{c}\text { Редакція від } \\
04.01 .2013 \\
\end{array}$ & $\begin{array}{c}\text { діяльність, що спрямована на розроблення й використання у сфері освіти результатів наукових } \\
\text { досліджень та розробок }\end{array}$ \\
\hline $\begin{array}{c}\text { Редакція від } \\
08.05 .2015\end{array}$ & $\begin{array}{c}\text { діяльність, що спрямована на розроблення й використання у сфері освіти результатів наукових } \\
\text { досліджень та розробок }\end{array}$ \\
\hline $\begin{array}{c}\text { Редакція від } \\
31.10 .2017\end{array}$ & $\begin{array}{c}\text { діяльність, що спрямована на розроблення й використання у сфері освіти результатів наукових } \\
\text { досліджень та розробок }\end{array}$ \\
\hline \multicolumn{2}{|r|}{ Визначення терміну «освітні інновації» } \\
\hline $\begin{array}{c}\text { Редакція від } \\
07.11 .2000\end{array}$ & $\begin{array}{c}\text { вперше створені, вдосконалені або застосовані освітні, дидактичні, виховні, управлінські системи, їх } \\
\text { компоненти, що суттєво поліпшують результати освітньої діяльності }\end{array}$ \\
\hline $\begin{array}{c}\text { Редакція від } \\
04.01 .2013\end{array}$ & $\begin{array}{c}\text { вперше створені, вдосконалені освітні, навчальні, виховні, управлінські системи, їх компоненти, що } \\
\text { мають істотно поліпшити результати освітньої діяльності }\end{array}$ \\
\hline $\begin{array}{c}\text { Редакція від } \\
08.05 .2015 \\
\end{array}$ & $\begin{array}{c}\text { вперше створені, вдосконалені освітні, навчальні, виховні, управлінські системи, їх компоненти, що } \\
\text { мають істотно поліпшити результати освітньої діяльності }\end{array}$ \\
\hline $\begin{array}{l}\text { Редакція від } \\
31.10 .2017\end{array}$ & $\begin{array}{l}\text { новостворені (застосовані) або вдосконалені освітні, навчальні, виховні, психолого-педагогічні } \\
\text { та управлінські технології, методи, моделі, продукція, освітні, а також технічні рішення у галузі } \\
\text { освіти, що істотно підвищують якість, результативність та ефективність освітньої діяльності }\end{array}$ \\
\hline \multicolumn{2}{|r|}{ Визначення терміну «об’скти інноваційної освітньої діяльності» } \\
\hline $\begin{array}{c}\text { Редакція від } \\
04.01 .2013\end{array}$ & \begin{tabular}{|l} 
нові знання, інноваційні освітні програми і проєкти, навчальний та виховний процеси, організаційні \\
та адміністративні рішення, а також рішення іншого характеру, що істотно поліпшують якість освіти
\end{tabular} \\
\hline $\begin{array}{c}\text { Редакція від } \\
08.05 .2015\end{array}$ & $\begin{array}{l}\text { нові знання, інноваційні освітні програми і проєкти, навчальний та виховний процеси, організаційні } \\
\text { та адміністративні рішення, а також рішення іншого характеру, що істотно поліпшують якість освіти }\end{array}$ \\
\hline $\begin{array}{l}\text { Редакція від } \\
31.10 .2017\end{array}$ & $\begin{array}{c}\text { нові емпіричні та/або теоретичні знання, навчальний та виховний процеси, освітні (педагогічні), } \\
\text { дидактичні, виховні, управлінські системи, моделі, методи, інноваційні освітні програми і проєкти, інші } \\
\text { інтелектуальні продукти, засоби навчання та обладнання, організаційні та адміністративні рішення, а також } \\
\text { рішення іншого характеру, що істотно поліпшують якість освіти, результативність та ефективність освітньої } \\
\text { діяльності педагогічних та науково-педагогічних працівників, навчальних закладів }\end{array}$ \\
\hline
\end{tabular}


Термін «метод» у найбільш загальному розумінні означає спосіб, прийом або систему прийомів для досягнення якої-небудь мети, для виконання певної операції.

Словник української мови (1970-1980) містить такі визначення терміну «метод»:

1. «Спосіб пізнання явищ природи та суспільного життя.

2. Прийом або система прийомів, що застосовується в якій-небудь галузі діяльності (науці, виробництві тощо)» [Словник].

Однак у сучасній науці розрізняють три його значення: загальнометодологічне (метод як спосіб пізнання дійсності, природних і суспільних явищ), загальнодидактичне та власнеметодичне (метод як спосіб (засіб) навчання або викладання).

Цікаво, що в сучасній зарубіжній педагогіці вищої школи (здебільшого в англійській та американській педагогіці) поняття «метод навчання» включає: форму організації навчальної роботи, засіб передавання знань студентам, спосіб роботи викладача та студента. Іншими словами, терміни «метод», «форма», «прийом», «засіб» навчання не розрізняються та використовуються в еквівалентному значенні [Активізація : 15].

В Українському педагогічному словнику знаходимо тлумачення терміна «метод» «(грец. - шлях дослідження чи пізнання) - спосіб організації практичного й теоретичного освоєння дійсності, зумовлений закономірностями розглядуваного об'єкта» [Український : 205], а також терміна «методи навчання в школі» - упорядковані способи взаємопов' язаної діяльності вчителя й учнів, спрямовані на розв'язання навчальновиховних завдань» [Український : 206].

Метод викладання як загальнодидактичне поняття можна визначити як «сукупність способів і прийомів спільної діяльності суб'єктів навчального процесу, спрямованої на досягнення освітньої мети, виховання й розвитку особистості» [Артикуца : 5].

Традиційно термін «метод викладання» у розумінні «як сукупність способів і прийомів навчання певної дисципліни» вживається у формі множини - методи викладання, адже зрозуміло, що повноцінно навчати, застосовуючи лише якийсь один метод, неможливо. Часто для передачі змісту процесу навчання використовують термін «методика» як сукупність методів викладання певної науки, предмета.

В. В. Ягупов терміном методика позначає «конкретні принципи, форми та засоби використання методів, за допомогою яких здійснюється більш глибоке пізнання різноманітних педагогічних проблем та їх розв'язання... Вона містить опис сукупності методів, системи прийомів і засобів, що застосовуються для дослідження різних виховних явищ» [Ягупов].

У рамках досліджуваного питання нас більше цікавлять поняття «інноваційні методи» та «методики викладання», зокрема правничих дисциплін.

Якогось усталеного визначення понять «інноваційні методи» та «інноваційні методики навчання (викладання)» нам віднайти не вдалося. Більшість авторів, вживаючи ці терміни, частіше просто вказують на конкретні методи або методики, які, на їхню думку, є інноваційними. Так, наприклад, Н. В. Артикуца розглядає «інноваційні методики викладання як методики новизни, ефективності, дієвості, доцільності використання у сучасних умовах, серед яких найбільш витребуваними на сьогоднішньому ринку освітніх послуг $є$ активні та інтерактивні методики навчання» [Артикуца]. На іï думку, «поняття інноваційні методики викладання є полікомпонентним, оскільки об'єднує усі ті нові й ефективні способи навчання (здобуття, передачі й продукування знань), які сприяють інтенсифікації та модернізації навчального процесу, розвивають творчий підхід і особистісний потенціал його учасників» [Артикуца : 6].

Н. Софій відносить до інноваційних методів передусім активні методи навчання, які забезпечують особистісно зорієнтований підхід і розвиток критичного мислення [Софій].

О. В. Гуцул, Т. В. Бірюкова, А. В. Шалаєва вважають, що використання в процесі навчання інноваційних технологій, а саме інтерактивних та комп'ютерних, дозволяє вдосконалити форми та методи навчання [Hutsul : 29].

Отже, 3 огляду на вищенаведені тлумачень термінів «метод навчання», «інновація», «освітня інновація» пропонуємо сформулювали таке визначення поняття «інноваційний метод навчання» - це сукупність способів 
i прийомів навчання певної дисципліни, що відповідають вимогам сьогодення, істотно підвищують якість, ефективність та результативність навчально-виховного процесу, сприяють інтенсифікації та модернізації навчального процесу, розвивають творчий підхід і особистісний потенціал його учасників.

Враховуючи зміст Положення про порядок здійснення інноваційної освітньої діяльності, подаємо таке тлумачення терміну «інноваційний метод навчання» - це об'єкт інноваційної освітньої діяльності, новостворений (застосований) або вдосконалений метод у галузі освіти, що істотно підвищує якість, результативність та ефективність освітньої діяльності педагогічних та науково-педагогічних працівників, навчальних закладів.

Висновки. Підсумовуючи вищевикладене, робимо висновок, що інноваційні методи навчання у сфері викладання правничих дисциплін - це сукупність способів і прийомів навчання правничих дисциплін, що відповідають вимогам сьогодення, істотно підвищують якість, ефективність та результативність навчально-виховного процесу, сприяють інтенсифікації та модернізації навчального процесу, розвивають творчий підхід і особистісний потенціал його учасників, забезпечують набуття в процесі навчання студентами-правниками необхідних компетентностей.

\section{ЛІТЕРАТУРА}

1. Активізація навчального процесу у сучасній вищій школі: метод. огляд / уклад. Л. А. Якимова. Київ : ДП «Вид. дім «Персонал», 2010. 32 с.

2. Аналітичний звіт за результатами проекту «Залучення громадськості до формування рамки кваліфікацій правничої професії шляхом проведення аналізу обсягу знань, переліку навичок і вмінь, якими має володіти випускник юридичного вищого навчального закладу, щоб відповідати вимогам сучасного ринку праці» / Козьяков С. Ю. та ін. Київ : ВГО «Українська Асоціація Маркетингу», 2015. 131 с.

3. Артикуца Н. Інноваційні методики викладання дисциплін у вищій юридичній освіті. 2005. URL: http://ekmair.ukma.edu.ua/bitstream/handle/123456789/2424/?sequence=1 (дата звернення: 02.09.2021).

4. Енциклопедія освіти / Академія пед. наук України; головний редактор В. Г. Кремінь. Київ : Юрінком Інтер, 2008. $1040 \mathrm{c}$.

5. Концепція розвитку юридичної освіти: проект / Комітет 3 питань освіти, науки та інновацій. URL: http://kno.rada.gov.ua/fsview/75465.html (дата звернення: 02.09.2021).

6. Положення про порядок здійснення інноваційної освітньої діяльності: наказ Міністерства освіти і науки України від 07 листопада 2000 р. № 522. URL: https://zakon.rada.gov.ua/laws/show/z0946-00/ed20150508 (дата звернення: 02.09.2021).

7. Про вищу освіту: Закон України від 01 липня 2014 р. № 1556-VII. URL: https://zakon.rada.gov.ua/laws/ show/1556-18 (дата звернення: 02.09.2021).

8. Словник іншомовних слів / за ред. О. С. Мельничука. Київ, 1974. 865 с.

9. Словник іншомовних слів / Уклад.: С. М. Морозов, Л. М. Шкарапута. Київ : Наук, думка, 2000. 680 с.

10. Словник української мови: Академічний тлумачний словник української мови (1970-1980). В 11 т. URL: http://sum.in.ua (дата звернення: 02.09.2021).

11. Софій Н. Інноваційні методи навчання та викладання. Освіта. ua. 2007. URL: http://osvita.ua/school/ method/1663/ (дата звернення: 02.09.2021).

12. Український педагогічний словник / Семен Гончаренко : гол. ред. С. Головко. Київ : Либідь, 1997. 373 с.

13. Юридична енциклопедія: у 6 т. / Редкол. : Ю. С. Шемшученко (гол. редкол.) та ін. Київ : «Укр. енц.», 1998. T. 2. $691 \mathrm{c}$.

14. Ягупов В.В. Педагогіка. URL: https://sites.google.com/site/pedagogikasny/pedagogika/agupov-v-vpedagogika (дата звернення: 02.09.2021).

15. Hutsul O. V., Biryukova T. V., Shalajeva A. V. Introduction of innovative technologies while teaching the course "Medical informatics". Modern engineering and innovative technologies. 2018. Issue 4 / Vol.1. Pp. 29-34. URL: https:/journals.indexcopernicus.com/api/file/viewByFileId/773251.pdf (дата звернення: 02.09.2021).

\section{REFERENCES}

1. Yakymova L.A. (2010). Aktyvizatsiia navchalnoho protsesu u suchasnii vyshchii shkoli [Activation of the educational process in modern higher education]. K. : DP "Vyd. dim "Personal" [in Ukrainian].

2. Koziakov S.Iu. ta in. (2015). Analitychnyi zvit za rezultatamy proektu "Zaluchennia hromadskosti do formuvannia ramky kvalifikatsii pravnychoi profesii shliakhom provedennia analizu obsiahu znan, pereliku navychok $i$ vmin, yakymy maie volodity vypusknyk yurydychnoho vyshchoho navchalnoho zakladu, shchob vidpovidaty vymoham suchasnoho rynku pratsi" [Analytical report on the results of the project "Involvement of the public in the for- 
mation of the qualifications framework of the legal profession by analyzing the amount of knowledge, skills and abilities that a graduate of a law school must have to meet the requirements of the modern labor market"]. Kyiv: VHO "Ukrainska Asotsiatsiia Marketynhu" [in Ukrainian].

3. Artykutsa N. (2005). Innovatsiini metodyky vykladannia dystsyplin u vyshchii yurydychnii osviti [Innovative methods of teaching disciplines in higher legal education]. Retrieved from: http://ekmair.ukma.edu.ua/bitstream/handle/1234 $56789 / 2424 /$ ?sequence=1 [in Ukrainian].

4. Kremin V. H. (hol. red.). (2008). Entsyklopediia osvity [Encyclopedia of Education]. Akademiia ped. nauk Ukrainy. Kyiv: Yurinkom Inter [in Ukrainian].

5. Kontseptsiia rozvytku yurydychnoi osvity: proekt / Komitet z pytan osvity, nauky ta innovatsii. [The concept of legal education development: a project]. Retrieved from: http://kno.rada.gov.ua/fsview/75465.html [in Ukrainian].

6. Regulations on the procedure for carrying out innovative educational activities: order of the Ministry of Education and Science of Ukraine № 522. (2000, November 7). Retrieved from: https://zakon.rada.gov.ua/laws/show/z0946-00/ ed20150508 [in Ukrainian].

7. Law of Ukraine on the higher education № 1556-VII. (2014, July 1). Retrieved from: https://zakon.rada.gov.ua/ laws/show/1556-18 [in Ukrainian].

8. Melnychuk O.S. (Ed.). (1974). Slovnyk inshomovnykh sliv [Dictionary of foreign words]. Kyiv [in Ukrainian].

9. Morozov S. M., Shkaraputa L. M. (2000). Slovnyk inshomovnykh sliv [Dictionary of foreign words]. Kyiv : Nauk, dumka [in Ukrainian].

10. Slovnyk ukrainskoi movy: Akademichnyi tlumachnyi slovnyk ukrainskoi movy (1970-1980). [Dictionary of the Ukrainian language: Academic explanatory dictionary of the Ukrainian language (1970-1980)]. V 11 t. Retrieved from: http://sum.in.ua [in Ukrainian].

11. Sofii N. (2007). Innovatsiini metody navchannia ta vykladannia [Innovative methods of teaching and learning]. Osvita. ua. Retrieved from: http://osvita.ua/school/method/1663/ [in Ukrainian].

12. Honcharenko S., Holovko S. (hol. red.). (1997). Ukrainskyi pedahohichnyi slovnyk [Ukrainian pedagogical dictionary]. Kyiv: Lybid [in Ukrainian].

13. Shemshuchenko Yu. S. (hol. redkol.) ta in. (1998). Yurydychna entsyklopediia: u 6 t. [Legal encyclopedia: in 6 volumes]. Kyiv: «Ukr. ents.». T.2. [in Ukrainian].

14. Yahupov V. V. Pedahohika [Pedagogy]. Retrieved from: https://sites.google.com/site/pedagogikasny/pedagogika/ agupov-v-v-pedagogika [in Ukrainian].

15. Hutsul O. V., Biryukova T. V., Shalajeva A. V. (2018). Introduction of innovative technologies while teaching the course "Medical informatics". Modern engineering and innovative technologies. Issue 4. 29-34. Retrieved from: https://journals.indexcopernicus.com/api/file/viewByFileId/773251.pdf

\section{A. KHLYSTIK}

Senior Lecturer at the Department of Law,

Private Higher Education Institution Academy of Recreational Technologies and Law,

Lutsk, Ukraine

E-mail:mirahlystik@gmail.com

http://orcid.org/0000-0002-7154-2320

\section{CONTENT OF THE DEFINITION "INNOVATIVE TEACHING METHODS IN THE FIELD TEACHING OF LEGAL DISCIPLINES"}

The article considers theoretical approaches to defining the categories "innovation", "educational innovation", "innovative teaching method", "innovative teaching methods in the field of teaching legal disciplines". The approaches of various scientists to the definition of these categories are analyzed. The normative-legal acts in which it is possible to find the specified definitions are investigated. The author's interpretation of some of specified terms is offered.

Based on the most common interpretations of the terms "teaching method", "innovation", "educational innovation", it is proposed to formulate the following definition of "innovative teaching method" - a set of methods and techniques of teaching a discipline that meet today's requirements, significantly improve quality, efficiency and the effectiveness of the educational process, contribute to the intensification and modernization of the educational process, develop a creative approach and personal potential of its participants.

Given the content of the Regulations on the implementation of innovative educational activities, the following interpretation of the term "innovative teaching method" is an object of innovative educational activities, newly created 
(applied) or improved method in education, which significantly increases the quality, effectiveness and efficiency of educational activities of scientific and pedagogical workers, educational institutions.

It is concluded that innovative teaching methods in the field teaching of legal disciplines are a set of methods and techniques of teaching legal disciplines that meet today's requirements, significantly improve the quality, efficiency and effectiveness of the educational process, promote intensification and modernization of the educational process, develop creativity and personal potential of its participants, ensure the acquisition in the learning process by law students of the necessary competencies.

Key words: innovations, educational innovations, innovative teaching methods, innovative teaching methods in the field of law, legal education. 